\title{
Phospholipid Fatty Acid (PLFA) Analysis of Rhizosphere Bacterial Communities in a Peat Soil
}

\author{
A. HALBRITTER and T. MOGYORÓSSY \\ Research Institute for Soil Science and Agricultural Chemistry (RISSAC) of the \\ Hungarian Academy of Sciences, Budapest
}

In Europe most peatlands (fens, bogs) have already disappeared due to human activity. This is true also for Hungary, where the constantly water-saturated peat soil (peatland) area decreased from $1000 \mathrm{~km}^{2}$ to $400 \mathrm{~km}^{2}$ between 1915 and 1975 (DÖMSÖDI, 1988). According to recent trends, it is favourable to increase the peatland area, due to the peat soil's important carbon sink and water purification functions. For wastewater post-treatment, low cost artificial wetlands are already in use. Peat soils, however, release greenhouse gases, mainly methane (SUNDH et al., 1995), so in artificial wetlands methane oxidation in the upper aerobe layers must be enhanced.

Although wetlands have an important role in biogeochemical cycles, wetland microbial communities have not been studied intensively. The scarce research work that has been carried out has focused on the taxonomic identification of some isolated strains (BRUNEL et al., 1992) and on the microbial communities of the peat itself (BORGA et al., 1994; SUNDH et al., 1997).

In present research we concentrated on the quantitative structure of rhizosphere and peat soil bacterial communities. Our main aim was to determine the rhizosphere effect of four dominant wetland plants (from the same fen), as in the rhizosphere the shortage of oxygen is reduced due to the air transported by the roots' aerenchimatic tissues (ARMSTRONG, 1964). Our indirect approach was based on the chemical analysis of indicative biomolecules, the so-called biomarkers (MORGAN et al., 1997). Among different potential biomarkers the quantitative analysis of phospholipid fatty acids (PLFA) provides biomass-related information for various bacterial groups, including the nonculturables (which can be $99 \%$ in soils according to TORSVIK et al., 1990). Unlike DNA-based methods, only the living cells are considered (phospholipids degrade quickly after death). In the last decade, PLFA analysis has been widely

Correspondence to: András HALBRITTER, Research Institute for Soil Science and Agricultural Chemistry (RISSAC) of the Hungarian Academy of Sciences, H-1022 Budapest, Herman Ottó út 15. Hungary. E-mail: hal@rissac.hu 
applied to soil and water samples. It has proven to be an important tool in assessing soil quality related parameters based on the soil ecosystem structure (ZELLES et al., 1992). We have tried to apply this approach to the rhizosphere. However, absolute bacterial biomass estimation was not possible as the fatty acids also occurring in plants were neglected in the data analysis, and because there are no conversion factors for calculating bacterial biomass out of the amounts of bacteria-specific fatty acids. Hence, also the fatty acids of fungi were neglected, so in present work we refer to bacterial, and not microbial abundance, community structure, etc.

\section{Materials and Methods}

The samples were collected from a floating peat fen of the Danube near Szigetcsép (Csepel Island, Hungary) in September 2001. Samples were stored at $4{ }^{\circ} \mathrm{C}$ during transport. From 2-2 g (dwt) homogenized peat soil and four wetland plant (lesser bulrush, Typha angustifolia L.; cyperus sedge, Carex pseudocyperus L.; marsh fern, Thelypteris palustris Salisb.; grey willow, Salix cinerea L.) roots (collected from the upper $0.3 \mathrm{~m}$, excluding rhizomes) the total lipid content was extracted (ZELLES \& BAI, 1993) in duplicates. As we extracted total root samples after a careful removal of peat soil particles, the sensu lato rhizosphere (the rhizoplan, the endo-, and ectorhizosphere) was investigated. The phospholipid fraction was separated by solid phase chromatography (ZELLES \& BAI, 1993). This fraction is the main component of cell membranes, and the amount of this fraction reflects the biomass. Fatty acids were liberated from the phospholipids, and to ensure qualitative determination fatty acid mixtures were fractionated on solid phase columns (ZELLES \& BAI, 1993) and derivatized (methyl, DMDS and TMSI derivatives). This way esther-linked saturated (SATFA), esther-linked monounsaturated (MUFA), esther-linked poliunsaturated (PUFA), esther-linked hydroxi-substitued (PLOH), non-esther-linked (unsaponifiables) unsubstituated (UNSFA) and hydroxi-substituated (UNOH) fractions were prepared and analyzed separately on a HP 5971A-HP 5890 series II Gas Chromatograph-Mass Spectrometer, on a capillary column $(50 \mathrm{~m} \times 0.2$ $\mathrm{mm}$ i.d., $0.33 \mu \mathrm{m}$ thick coated with cross-linked $5 \%$ phenylmethyl silicon phase), with $\mathrm{He}$ carrier gas at a flow rate of $1.0 \mathrm{ml} \mathrm{min}^{-1}$, the quadrupole mass spectrometer was used in scanning mode. Quantitation was achieved by comparing the peak area of the compound of interest and of the internal standard (methyl-nonadecanoate), considering the detector response of the different fatty acid types, determined by external standards. All fatty acid fractions were prepared and analyzed according to ZELLES (1996). From the fatty acids only the bacteria-specific ones were used: the hydroxi-substituated, the cyclo chained and the branched chain fatty acids, all others were neglected in the data analysis, as they occur also in plants. Indicative value, taxonomic occurrence 
and specificity of fatty acid types is derived from literature data (BALOWS et al., 1992; ZELLES, 1999).

\section{Results and Discussion}

\section{The rhizosphere effect in peat soil}

The total amount of bacteria-specific fatty acids per dry weight was higher for each plant root sample, than for the peat soil: a strong concentration of bacteria was demonstrated in the rhizosphere. This result suggests that rhizosphere is the habitat type for an important part in the bacterial biomass of peatlands (Figure 1). As it can be seen in Figure 1, the rhizosphere effect of the Typha proved to be the highest (25.0-times higher total amount, as compared to the peat soil). The rhizosphere effect was estimated to be 20.0, 8.5 and 7.5 in case of the Salix, Carex and Thelypteris species, in comparison to the peat soil.

\section{Ratio of aerobe and anaerobe bacteria in the rhizosphere and in the peat soil}

Non-esther-linked fatty acids occur mainly in anaerobic bacteria. The relative amounts of esther-linked/non-esther-linked fatty acids indicate the redox potential of the microenvironment. Figure 2 shows the relative amounts of esther- and non-esther-linked fatty acids as a percentage of the total fatty acid content in the sample. Salix rhizosphere seems to be more anoxic than the peat, while Carex, Typha and Thelypteris rhizospheres show a higher relative abundance of aerobic bacteria. In case of these later plant species we observed a strong canalization of air transporting lacunae (aerenchymatic tissue) in the root system. The highest ratio of aerobic bacteria occurred on Thelypteris roots, which explains the fact that we could find methanotroph-specific fatty acids

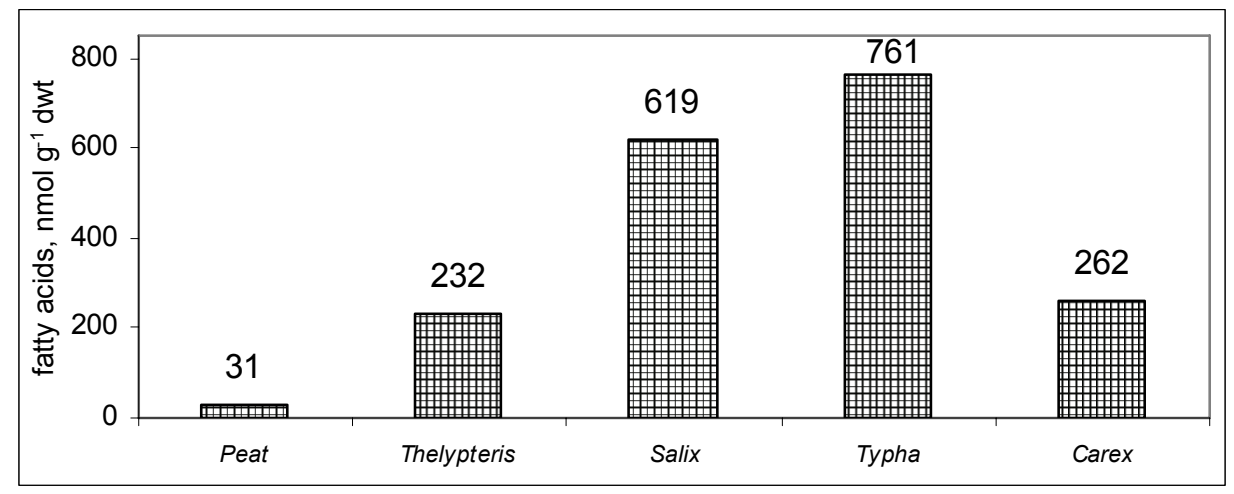

Figure 1

Total amount of the bacteria-specific fatty acids in the peat soil and roots 


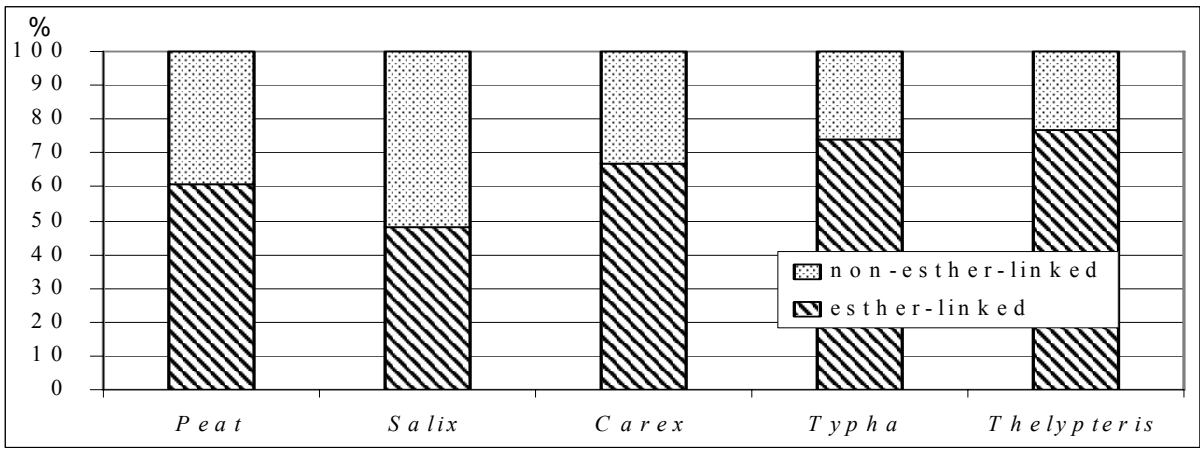

Figure 2

Relative amount of esther-linked and non-esther-linked fatty acids in the peat soil and in the rhizosphere

only in this species $\left(5.8 \mathrm{nmol} \mathrm{g} \mathrm{g}^{-1} \omega 8-16: 1\right.$ and $11.9 \mathrm{nmol} \mathrm{g}^{-1} \omega 8$ 18:1 fatty acids: 16 and 18 carbon atom long chain with a double bond at the 8th position, numbered from the aliphatic end). The application of Thelypteris on artificial wetlands therefore is highly suggested, in order to reduce methane emission.

\section{Bacterial community structures in the rhizosphere and in the peat soil}

The samples were found to differ significantly in their bacterial community structures. In Figures 3 and 4 iso and anteiso fatty acids indicate that Gram positives were most abundant on Carex roots, aerobe Gram-negatives on Typha roots (based on the amount of esther-linked, EL-cyclo acids). The quantity of

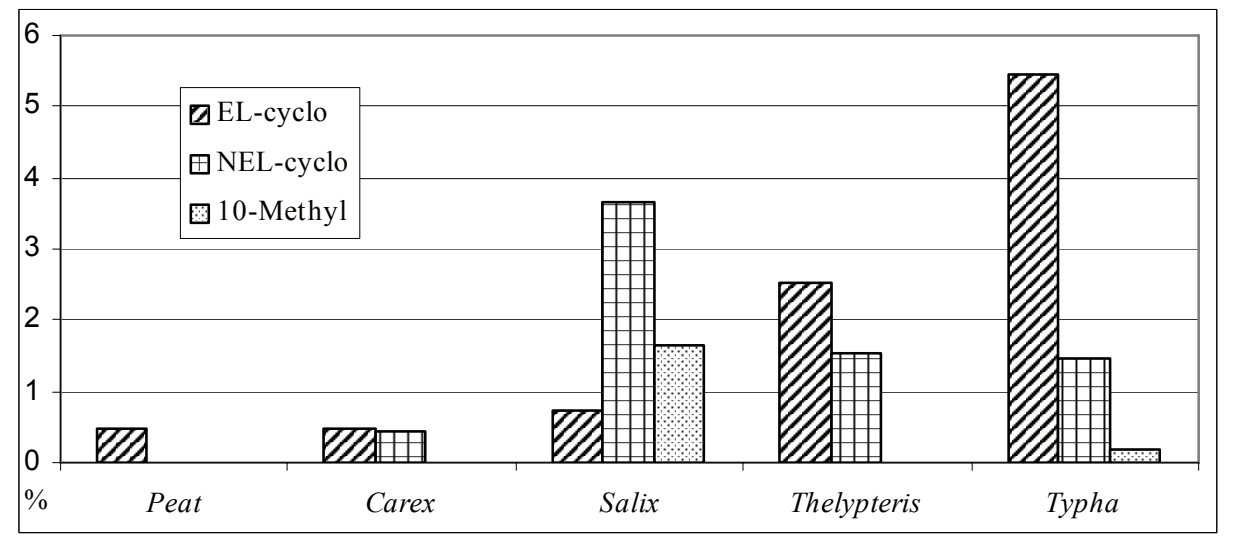

Figure 3

Relative amounts of EL-cyclo (aerobe Gram-negatives), NEL-cyclo (anaerobe Gramnegatives) and 10-methyl (sulphate reducers) fatty acids in the peat soil and in the rhizosphere 


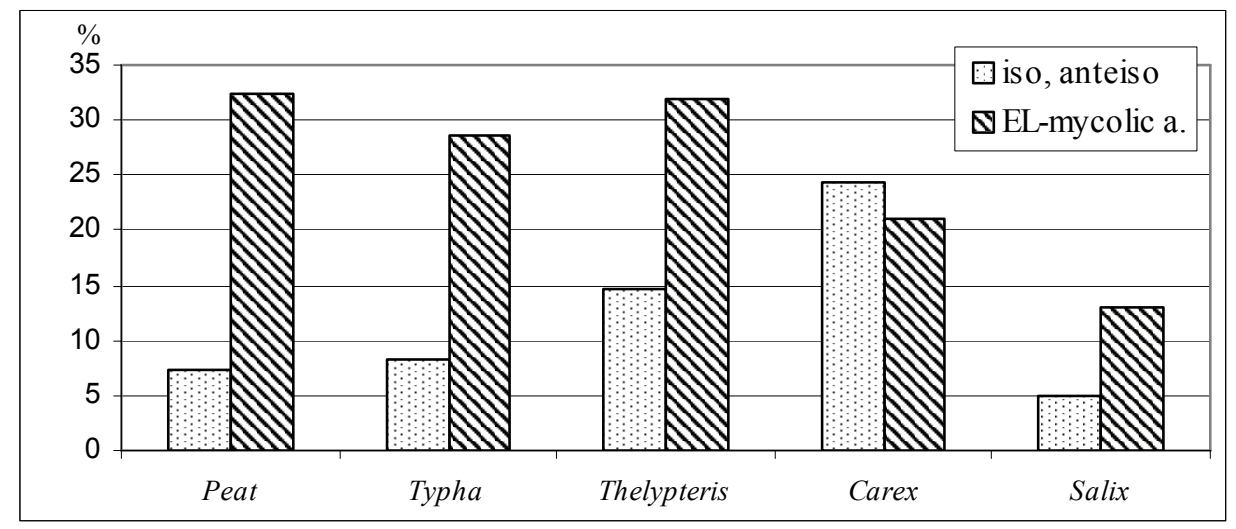

Figure 4

Relative amounts of esther-linked iso, anteiso fatty acids (end-chain or pre-end-chain methyl group, Gram-positives) and mycolic -acids (aerobe Actinobacteria) acids in the peat soil and in the rhizosphere

EL-mycolic acids indicates high numbers of aerobe or microaerophilic Actinobacteria with Thelypteris roots and in the peat. Non-esther linked cyclo fatty acids indicate that Salix roots attract anaerobe Gram-negatives and sulphate reducers (non-esther-linked, NEL-cyclo and 10-methyl fatty acids). The PLFA analysis made it possible to assess microbial structure and indicate soil chemical parameters without neglecting non-culturable bacteria, unlike plate count based methods (e.g. ANGERER et al., 1998). It was demonstrated that PLFA analysis is applicable on the real rhizosphere, and not only on rhizosphere adhered soil. Other microbial biomass estimation methods like chloroform fumigation extraction method (ANDERSON \& DOMSCH, 1978, SzILI-KOVÁCS et al., 1998) are not applicable on the rhizosphere due to the organic carbon released from plant root cells.

\section{Summary}

To analyze the rhizosphere bacterial communities in wetlands, the total lipid content was extracted from a peat soil and 4 abundant wetland plant roots (Typha angustifolia L., Salix cinerea L., Carex pseudocyperus L., Thelypteris palustris Salisb.). The separated phospholipid fraction was further fractionated and derivatized prior to gas chromatography-mass spectrometry (GC-MS) measurement. In the evaluation only the bacteria-specific fatty acids were used in order to neglect fatty acid information derived from plant root cells. Based on these analyses, a high level bacterial concentration was demonstrated in the rhizosphere, and the relative occurrence of aerobe and anaerobe, Gram positive and negative bacteria, methanotrophs, sulphate reducers and Actinobacteria was determined. Through the PLFA analysis the study of bacteria regardless of culturability was possible. 
Key words: rhizosphere effect, PLFA, Carex, Salix, Typha, Thelypteris

\section{References}

Anderson, J. P. E. \& DomsCH, K. H., 1978. A physiological method for the quantitative measurement of microbial biomass in soil. Soil Biol. Biochem. 10. 215-221.

ANGERER, I. P. et al., 1998. Indicator microbes of chlorsulfuron addition detected by a simplified plate counting method. Agrokémia és Talajtan. 47. 297-304.

ARMSTRONG, W., 1964. Oxygen diffusion from the roots of some British bog plants. Nature. 204. 801-802.

BAlows, A. et al. (Eds), 1992. The Prokaryotes. A Handbook on the Biology of Bacteria: Ecophysiology, Isolation, Identification, Applications. $2^{\text {nd }}$ ed. Springer-Verlag. New York.

Borga, P., Nilsson, M. \& Tunlid, A., 1994. Bacterial communities in peat in relation to botanical composition as revealed by phospholipid fatty acid analysis. Soil Biol. Biochem. 26. 841-848.

BRUNEL, B. et al., 1992. Effect of transient oxic conditions on the composition of the nitrate-reducing community from the rhizosphere of Typha angustifolia. Microb. Ecol. 24. 51-61.

DöMSÖDI, J., 1988. Changes in peatlands. (In Hungarian) Agrokémia és Talajtan. 3637. $127-150$.

Morgan, J. A. W. \& Winstanley C., 1997. Microbial biomarkers. In: Modern Soil Microbiology. (Eds.: Elsas, J. D., Trevors, J. T. \& Wellington, E. M. H.) 331-347. Marcel Dekker. New York.

SundH, I., NilsSON, M. \& BORGA, P., 1997. Variation in microbial community structure in two boreal peatlands as determined by analysis of phospholipid fatty acid profiles. Appl. Environ. Microbiol. 63. 1476-1482.

SuNDH, I. et al., 1995. Estimation of cell numbers of methanotrophic bacteria in boreal peatlands based on analysis of specific phospholipid fatty acids FEMS. Microbiology Ecology. 18. 103-112.

SzILI-KovÁCS, T. et al., 1998. Soil microbial biomass-C as a possible indicator of soil pollution. Agrokémia és Talajtan. 47. 253-264.

TORSVIK, V., GOKSOYR, J. \& DAAE, F. L., 1990. High diversity in DNA of soil bacteria. Appl. Environ. Microbiol. 56. 782-787.

ZELLES, L., 1996. Fatty acid patterns of microbial phospholipids and lipopolysaccharides. In: Methods in Soil Biology. (Eds.: SCHINNER, F. et al.) 80-93. Springer Verlag. Berlin.

ZELLES, L., 1999. Fatty acid patterns of phospholipids and lipopolysaccharides in the characterisation of microbial communities in soil: a review. Biol. Fertil. Soils. 29. 111-129.

ZELLES, L. \& BAI, Q. Y., 1993. Fractionation of fatty acids derived from soil lipids by solid phase extraction and their quantitative analysis by GC-MS. Soil Biol. Biochem. 25. 495-507.

ZELLES, L. et al., 1992. Signature fatty acids in phospholipids and lipopolysaccharides as indicators of microbial biomass and community structure in agricultural soils. Soil Biol. Biochem. 24. 317-323. 